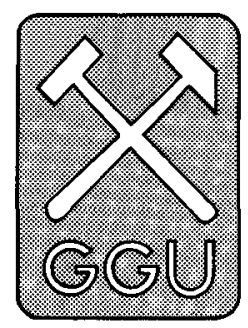

Exceptionally preserved fossils of soft-bodied animals have always aroused particular interest within the geological community. Not only do they supply anatomical information not usually preserved, but they also provide insights into the structure of the living communities which are difficult to obtain from fossils preserved as hard skeletal elements alone. The importance of these soft-bodied or poorly skeletised forms is indicated by their dominance in present day environments where animals without hard parts make up more than two thirds of the number of species and individuals present (Conway Morris, 1986).

The most famous assemblage of exceptionally preserved soft-bodied fossils occurs within the Middle Cambrian Burgess Shale of British Columbia, Canada. The locality was discovered in the early part in this century by the eminent American palaeontologist Charles D. Walcott whose many contributions to Cambrian geology are recognised by the land area of North Greenland which bears his name (fig. 1). Burgess Shale fossils have been described by many authors, but most notably in a series of monographs by Walcott himself and by a group established at the University of Cambridge, England, under the leadership of Professor $\mathrm{H}$. B. Whittington (see Conway Morris, 1986 for references). A recent 'best-seller' evaluates the significance of this "most precious and important of all fossil localities" in terms of the development of life during the 500000000 years since the Cambrian (Gould, 1989, p. 13). Gould suggests that the importance of the Burgess Shale assemblage has been underestimated since earlier work tended to interpret many of the fossils in terms of classifications largely based on present-day taxa, rather than recognising the diversity inherent within the assemblage itself.

The Burgess Shale assemblage contains more than 100 species, but only some $2 \%$ of the 40000 individuals counted by Conway Morris (1986) contain hard parts capable of preservation under normal geological circumstances. This latter group includes trilobites and hyolithids, readily fossilised on account of their calcareous skeletons and thus familiar to students of Cambrian fossils. The remaining species consist of a wide range of

\section{Studying the early history of life in Greenland}

\author{
John S. Peel
}

animals ranging from arthropods, which dominate the collections both in terms of the abundance of species and individuals, to sponges and bizarre fossils which can not be accommodated within current schemes of classification. Many of these fossils preserve exquisite details of soft tissues, including limbs and gills.

One of the most interesting aspects of the Burgess Shale assemblage is its antiquity (more than 520000000 years). It provides a window through which the early evolution of highly organised life can be studied, occurring some few tens of millions of years after one of the greatest events in the history of life. This event, often referred to as the 'Cambrian explosion', took place near the Precambrian-Cambrian boundary (550000 000 years ago) and resulted in the relatively sudden appearance of highly developed organisms within the fossil record.

It is clearly of some consequence that an assemblage of Burgess Shale-like fossils some 20000000 years older than those preserved within the Burgess Shale has been discovered recently in Greenland. This assemblage was discovered by A. K. Higgins within the Lower Cambrian Buen Formation in north-western Peary Land (fig. 1) during the final stages of a regional geological project instigated by the Geological Survey of Greenland (GGU) in North Greenland (1978-1980 and 1984-1985). Unfortunately, the significance of the assemblage was not recognised until the collections were examined in Copenhagen early in 1986, by which time it was no longer possible to revisit the locality within the logistic framework established for the North Greenland project.

Apart from sponges described by Rigby (1986) and many specimens of a single species of nevadiid trilobite, subsequently described as Buenellus higginsi gen. et sp. nov. by Blaker (1988), the small collection made by Higgins contained a number of species of poorly skeletised arthropods. The discovery was reported and briefly described by Conway Morris et al. (1987). The assemblage was considered to be of special interest not only on account of its excellent preservation (cf. fig. 2) but also because it demonstrated the presence of an animal community of similar structure to that of the 


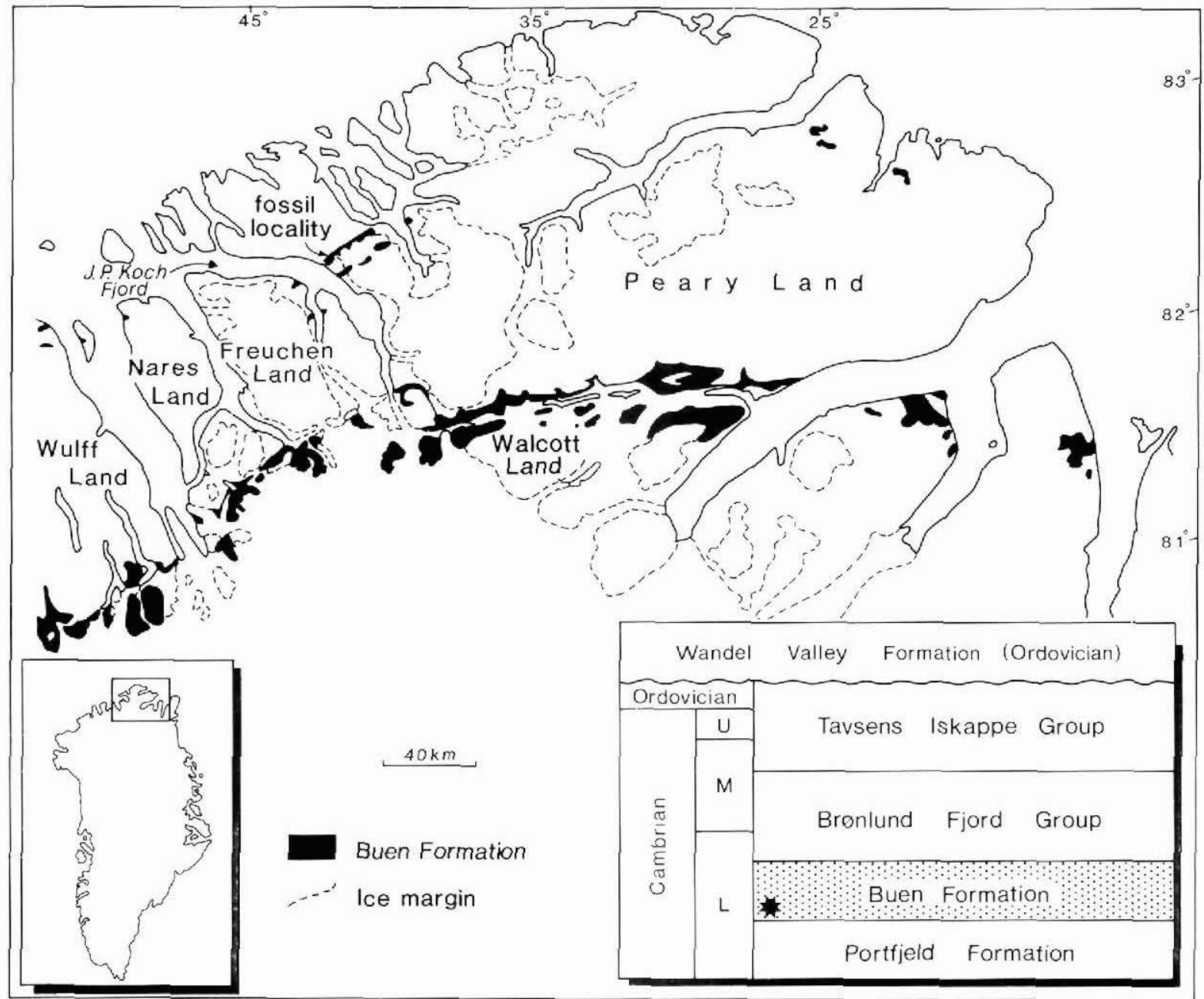

Fig. 1. Locality for exceptionally preserved fossils from the Buen Formation in North Greenland. The occurrence of the assemblage within the lower part of the Buen Formation is starred (inset).

Middle Cambrian Burgess Shale in substantially older Lower Cambrian strata.

During July 1989 a 4-man group revisited the locality to make larger collections and to try and assess the extent of the fossiliferous deposits. The expedition was made possible by a generous grant from the Carlsberg Foundation, Copenhagen, and logistical support from GGU's geological mapping programme in North-East Greenland (see Henriksen, 1990). Despite problems with poor weather, a collection of more than 1500 rock samples was secured.

Almost all the fossils were derived from approximately $5 \mathrm{~m}$ of shale occurring at a single locality near $\mathrm{J}$. P. Koch Fjord. The fossiliferous shales apparently occur within the lower part of the Buen Formation and not within the upper part, as had been suggested by Conway Morris et al. (1987).
The most common fossils within the more than 30 species currently recognised are arthropods, some of which must have exceeded half a metre in length during life. Most conspicuous are large specimens of the trilobite Buenellus higginsi but bivalved carapaces of ostracode-like species (length 1-2 cm) are numerically dominant. Other species vary from elongate forms with abundant segments to squat, ovoid arthropods with fewer segments and large head and tail shields of similar proportions. Many specimens of the latter group preserve traces of limbs, gills and possible enteric musculature (fig. 2). Sponges and worms are well represented but brachiopods and echinoderms are apparently absent. Molluses are represented by a few small capshaped shells of uncertain affinity. Hyolithids are also rare but some preserve the operculum and appendages ('helens'). 

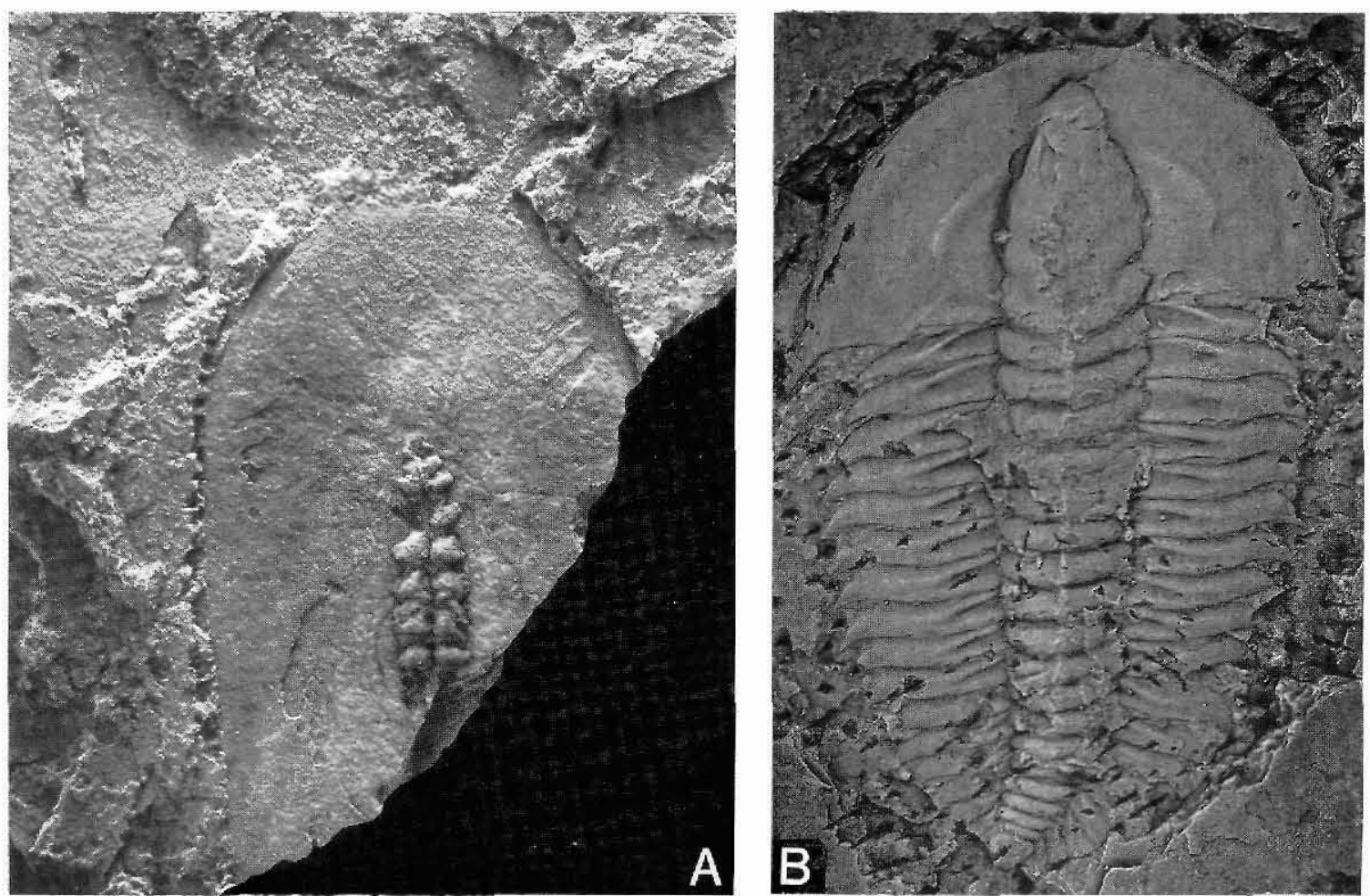

Fig. 2. Fossils from the Lower Cambrian Buen Formation near J. P. Koch Fjord, central North Greenland. A, an arthropod lacking mineralisation of the exoskeleton, MGUH 17.512 from GGU sample 319571. Note the segmentation of the thorax and the prominent mould of the body cavity. The head shield carries a pair of antennae, the right one of which is clearly visible, $\times 1.5$. B, the trilobite arthropod Buenellus higginsi Blaker, 1988, in which the exoskeleton is heavily mineralised, MGUH 17.590 from GGU sample $319571, \times 2$.

Several taxa currently defy classification. Most notable amongst these is a worm-like species (length $c .5 \mathrm{~cm}$ ) covered with a dense thatch of pointed spines but with larger ovoid plates at both extremities. This remarkable taxon promises to be the key to unravelling the affinities of a number of described taxa of spine-like microfossils which are common in Lower Cambrian strata from many areas (Conway Morris \& Peel, 1990).

The assemblage of poorly skeletised fossils from the Buen Formation is being studied by a group of palaeontologists centred around the University of Cambridge and the Geological Survey of Greenland. The investigations will write not only a new chapter on ancient life in Greenland but also contribute to the understanding of the early history of life on earth.

Acknowledgements. Fellow expedition members Simon Conway Morris (Cambridge), Paul Smith (Geological Museum, Copenhagen) and Poul Schiøler (GGU) are thanked for making the trip to Peary Land a success. The programme, financed by the Carlsberg Foundation, was supported logistically by GGU, the 'Sirius' sledge patrol and the Royal Danish Air Force.

\section{References}

Blaker, M. R. 1988: A new genus of nevadiid trilobite from the Buen Formation (Early Cambrian) of Peary Land, central North Greenland. Rapp. Gronlands geol. Unders. 137, 33-41.

Conway Morris, S. 1986: The community structure of the Middle Cambrian Phyllopod Bed (Burgess Shale). Palaeontology 29, 423-467.

Conway Morris, S. \& Peel, J. S. 1990: Articulated halkienids from the Lower Cambrian of north Greenland. Nature 345, 802-805

Conway Morris, S., Peel, J. S., Higgins, A. K., Soper, N. J. \& Davis, N. C. 1987: A Burgess shale-like fauna from the Lower Cambrian of North Greenland. Nature 326, 181-183.

Gould, S. J. 1989: Wonderful life. The Burgess Shale and the nature of history, $347 \mathrm{pp}$. New York: W. W. Norton \& Co.

Henriksen, N. 1990: Regional geology and 1:500 000 mapping in North-East Greenland. Rapp. Grønlands geol. Unders. 148 (this volume).

Rigby, J. K. 1986: Cambrian and Silurian sponges from North Greenland. Rapp. Gronlands geol. Unders. 132, 51-63.

\section{J. S. P., Geological Survey of Greenland, Copenhagen.}

